\title{
Assessing the Effective Communication Channels to Reduce Child and Adolescent Marriage in Rural Communities of Egypt
}

\author{
Ammal M. Metwally ${ }^{1} \mathbb{D}$, Marwa El-Sonbaty ${ }^{2,3}$ D , Dalia Elmosalami ${ }^{1}$, Hala Amer $^{1,4}$ (D) , Manal Abuelela ${ }^{5}$, Hasanin Mohamed ${ }^{6}$, \\ Mohamed Ahmed $^{6}$ (D) Hatem Hasan ${ }^{7}$ (D) Amira Mohsen ${ }^{1}$ (D), Lobna El Etreby ${ }^{1}$, Ghada A. Abdel-Latif ${ }^{1}$, Nihad A. Ibrahim ${ }^{1}$, \\ Hanaa Emam ${ }^{8}$ (D) Aida Abdelmohsen ${ }^{1}$, Walaa Fouad ${ }^{1}$ (D), Somia I. Salama ${ }^{1}$, Iman Salama ${ }^{1}$, Rehan Saleh ${ }^{1 *}$ (D) \\ ${ }^{1}$ Department of Community Medicine Research, Medical Research and Clinical Studies Institute, National Research Centre, \\ Dokki, Cairo, Egypt; ${ }^{2}$ Department of Child Health, Medical Research and Clinical Studies Institute, National Research Centre, \\ Dokki, Cairo, Egypt; ${ }^{3}$ Department of Pediatrics, College of Medicine, Taibah University, Madinah, Kingdom of Saudi Arabia; \\ ${ }^{4}$ Department of Infection Control, King Saud Medical City, Riyadh, Kingdom of Saudi Arabia; ${ }^{5}$ Department of Public Health, \\ Research Institute of Ophthalmology, Giza, Egypt; ${ }^{6}$ Department of Pediatrics, Medical Research and Clinical Studies Institute, \\ National Research Centre, Dokki, Cairo, Egypt; ${ }^{7}$ Department of Reproductive Health, Medical Research and Clinical Studies \\ Institute, National Research Centre, Dokki, Cairo, Egypt; ${ }^{8}$ Department of Skin and Venereal Diseases Research, Medical \\ Research and Clinical Studies Institute, National Research Centre, Dokki, Cairo, Egypt
}

\begin{abstract}
BACKGROUND: Low levels of scholarly achievement, poverty, and geographical isolation are all known to be linked to early marriage.

AIM: This study aimed at identifying the most credible and the best-suited communication channels (CCs) to reach rural communities for motivating them to reduce child and adolescent marriage.

METHODS: This study was a community-based cross-sectional systematic formative research. The study targeted 1000 wives who were ever married women in childbearing period aged 15-49 years and their husbands in 21 rural village units of two governorates of Upper Egypt through questionnaires. Decisions concerning the choice of the best-suited CCs were based on their reach, frequency, managerial feasibility, and effectiveness. The investigated CCs included: modern social media (search browser engine/Facebook group and/or twitter/YouTube or messaging through WhatsApp or any mobile app), traditional mass media (T.V/Radio/Reading), and interpersonal communication (talk with religious leaders/partners/friends/doctors/health promoters). Comparisons between different CCs were done using odds ratios $(\mathrm{OR})$ and $95 \%$ confidence intervals $(\mathrm{Cl})$.

RESULTS: A vast majority of the surveyed wives (96.6\%) were married at an age ranging from 15 to 24 years. The spread of social media through smartphones was limited to only one-third of wives and their husbands through mainly searching on YouTube (31.7\% of wives and $27.8 \%$ of husbands). Television was the most accessible means of mass media for both wives and husbands $(72.5 \%$ and $63.3 \%$, respectively). The most credible and the best-suited CCs methods for wives were talking with the health promotors and doctors with 2 times significantly higher $(\mathrm{OR}=2.0, \mathrm{Cl}=1.7-$ 2.4 for each one) than that with the search on YouTube and 3 times significantly higher $(\mathrm{OR}=3.1, \mathrm{Cl}=2.5-3.7$ and $\mathrm{OR}$ $=3.1, \mathrm{Cl}=2.6-3.8$, respectively) than that for social media using browser engine. For husbands, the odds of the most credible and the best-suited CCs methods were more than $1 \frac{1}{2}$ times higher for the talk with the health promotors than the search on You Tube $(\mathrm{OR}=1.6, \mathrm{Cl}=1.3-2.0)$ or the search using browser engine $(\mathrm{OR}=1.6, \mathrm{Cl}=1.3-1.9)$, Whereas the odds were one and a third higher for the talk with the doctor than the search on You Tube $(\mathrm{OR}=1.3, \mathrm{Cl}=1.1-1.6)$ or the search using browser engine $(\mathrm{OR}=1.6, \mathrm{Cl}=1.1-1.6)$. Significant difference was detected in favor of the traditional media as the most credible source of information only for wives' intention to postpone their children early marriage.

CONCLUSIONS: Despite the availability of recent social media worldwide, rural communities with high illiteracy have limited access to the internet and limited availability of smartphones. Interpersonal communication is considered their most effective CCs for achieving equity in reducing child marriage. It seems vital during the implementation of any strategies toward reproductive health to use not only the media broadcasts, but also to rely on the channels that are most credible and suitable for the targeted communication to support meeting the unmet need.
\end{abstract}

Edited by: Sasho Stolesk Citation: Metwally AM, EI-Sonbaty M, Elmosalami D, Amer $\mathrm{H}$, Abuelela M, Mohamed $\mathrm{H}$, Ahmed M, Hasan $\mathrm{H}$, Mohsen A, El Etreby L, Abdel-Latif GA, Ibrahim NA, malam H, Abdelmohsen A, Fouad W, Salama SI,
Saleh R. Assessing the Effective Communication Channels to Reduce Child and Adolescen Marriage in Rural Communities of Egypt. Open-Access Maced J Med Sci. 2021 Nov 20; 9(E):1288-1299 htps://doi.org/10.3889/oamjms.2021.7620 Keywords: Child marriage, Social media; Search Interpersonal communication; Mass media communication channels; Credibility

channels; Credibility
*Correspondence: Dr. Rehan Saleh, Department of blic Health and Community Medicine, Medical Research and Clinical Studies Institute, National Research Centre, Dokki, Giza, Egypt. E-mail: rehansaleh@yahoo.com Received: $17-$ Oct-202 Revised: 09-Nov-202 Accepted: 10-Nov-202
Copyright: $\odot 2021$ Ammal M. Metwally, Marwa El-Sonbaty, Dalia Elmosalami, Hala Amer, Hatem Hasan, Amira Mohsen, Lobna El Etreby, A. Abdel-Latif, Nihad A. Ibrahim, Hanaa Emam, Aida Abdelmohsen, Walaa Fouad, Somia I. Salama, Iman Salama, Rehan Sale Funding: This research did not receive any financial support
Competing Interest: The authors have declared that no
competing interest exists competing interest exists Open Access: This is an open-access article distributed
under the terms of the Creative Commons Attributionunder the terms of the Crealive Connons Atribution-

\section{Introduction}

Adolescence is defined as the transition period between childhood and adulthood (between ages 10 and 22 years) although age categories vary among different cultures [1]. A recent viewpoint defines the age between 10 and 24 years as age of adolescence [2].

One-third of girls in developing countries are married before the age of 18 and one in nine are married before the age of 15 [3]. Though the legal age of marriage has been set at 18 years old since 2008, child marriage is still frequently practiced in Egypt especially 
in rural communities because the law prohibits but does not criminalize the practice.

Marriage of a young daughter in Egypt allows parents to reduce household expenses and to gain a source of income through the dowry paid to the bride's family. The percentage of women aged 20-24 years who were married before the age of 18 had declined from $19.5 \%$ in 2000 to $16.6 \%$ in 2005 , remained steady at $16.6 \%$ from 2005 to 2008 and increased slightly to $17.4 \%$ in 2014 [4]. According to the Egypt Census of 2017 , child marriage declined with nearly 1 in every 20 girls $(5 \%)$ between age 15 and 17 years and 1 in every $10(10 \%)$ adolescent girls $15-19$ years are either currently married or were married before. Meanwhile, large significant differences were observed between rural and urban residence [5] indicating that child marriage remains an important issue among rural communities.

Early marriage deprives girls of education and employment opportunities and places them at risk of early and repeated pregnancy, gender-based violence, and sexually transmitted infections [6], [7]. Moreover, child and adolescent marriage can refrain economic empowerment in Egypt. Women's opportunity to learn and invade labor market in the future will decrease which can hinder Egyptian economic development, in addition to being a burden as they can experience more complications during pregnancy [8]. Moreover, many Egyptian studies concluded that young age at marriage is a cause of education deprivation and acts as a risk factor for child malnutrition and poor development [9], [10], [11], [12].

Women living in rural Upper Egypt have less access to high-quality obstetric care, making them about twice as likely to die from pregnancy as women in northern Egypt [13]. In 2013, Egypt developed the National Strategic Plan (NSP) for Prevention of Early Marriage, aiming to reduce the prevalence of early marriage by $50 \%$ within a 5 -year timeframe. However, due to the political situation in Egypt, the plan was not implemented because of the sensitive nature of the problem [14], [15]. Meanwhile, it is each woman's right to enjoy healthy reproductive life and improving adolescents' care seeking behaviors to have healthy children and happy families [16], [17], [18], irrespective to the feasibility of implementing NSP for prevention of early marriage.

The achievement of the global Sustainable Development Goals (SDGs) that are needed for the realization of the national development priorities requires that the beneficiaries and communities are informed about and engaged in the issues that most affect them. Moreover, empowering their decisionmakers with knowledge to influence their decisions and improve their lives is necessary. Mass media is one of the popular and cost-effective global public health promotion (HP) tools [19] as well local one [18]. Mass media (including radio, television, newspapers, magazines, leaflets, posters, and pamphlets) is proved to influence the use of health services. Many interesting findings showed that lack of access to mass media played a pivotal role for increasing child marriage, yet more effort is needed to highlight the implications and consequences of child marriage in low-income communities [20], [21].

In response to these findings, it was important to access our target audience and their direct influential decision makers and to dig deeper for identifying the most favorite and credible communication channels (CCs) that are essential for success of strategies needed for effective reproductive HP (RHP) for women in general and future adolescents' mothers.

The idea of the present study raised from the belief that any change requires recognizing the voices of those who would be targeted by the development of this change. The realization of equity in health through reducing child and adolescent marriage as a national development priority requires suitable strategies to achieve social movement.

The rational of our study was that to achieve the reduction of high prevalence of the child and adolescent marriage in rural communities, and it was crucial to investigate which CCs could be trusted and carry credibility for people living in these communities. Our research question was to what extent the information for RHP received by modern social media (through search browser engine and YouTube) are creditable as that received by the traditional way of communication (interpersonal and traditional communication).

For achieving this, our study aimed at assessing the suitable channels of communication that could be used in the future as cost-effective channels helping in changing the behaviors of the target population and achieving the reduction in the high child and adolescent marriage in rural communities.

\section{Methods}

\section{Study design}

This study was a community-based crosssectional systematic formative research. The study was conducted over 2 years through formative quantitative assessment research for CCs.

\section{Setting}

This study was conducted in 21 villages of two of the governorates of Upper Egypt namely, Benisuef and Fayoum governorates, which were ranked as the second and the third poorest governorates, respectively. The choice of the 22 villages of these two governorates 
was based of two facts: Poverty is heavily concentrated in the upper rural region of Egypt, where $63.5 \%$ of individuals are poor. The study governorates ranked low in socioeconomic standard and high in maternal mortality [22].

\section{Participants and inclusion criteria}

Two groups were targeted and included in this study. First group: Ever married women in childbearing period aged 15-49 years within the targeted villages in the selected governorates.

The second group: Women's husbands who were the main decision makers. Husbands were chosen as a second target group in the present study because most women reported that they followed the beliefs of their husbands for all the life decisions and even for HP related issues. Accordingly, women and their husbands were considered as the priority target groups for the study.

\section{Variables/data sources and measurements}

Quantitative data were obtained through a designed standardized questionnaire that was constructed to determine the favorite channels for communication out of the traditional mass media, modern social media, and interpersonal communication. The investigated CCs included: modern social media (search browser engine/Facebook group and/or twitter/ YouTube or messaging through WhatsApp or any mobile app), traditional mass media (T.V/Radio/Reading), and interpersonal communication (talk with religious leaders/partners/friends/doctors/health promoters). The questionnaire included sociodemographic characteristics of the study group about the current age of wife and husband and their age at first marriage, background information for the education level of the woman and her husband, and their employment status and their types of residencies. Decisions concerning the choice of these media were based on reach; what proportion of the target group is exposed to the media? Frequency: how often is the target group exposed to the media? Managerial feasibility: will it be possible for the future interventions to manage the use of the three most exposed media over time? and Effectiveness; what are the most credible information sources, the best-suited CCs methods, and means to reach the target group?

The questionnaire was designed according to UNICEF guidelines 2008, 1999a and b, and World Bank 2003 [23], [24], [25], [26], [27], with some modifications including the addition of social media as modern channel of communication.

The main questionnaire was subjected to pilot testing after its modification on women at their childbearing period attending the rural health units in the same villages that were targeted in Benisuef and Fayoum governorates (50 women from each governorate). Data from these women were not included in the analysis. The pilot test was performed aiming at testing feasibility of the study implementation and assessing the validation of the prepared questionnaire, and its internal consistencies. Based on pilot test, some modifications were done to the questionnaire.

Data collection was conducted by a research team from the National Research Centre of Egypt who were public health and adolescent health specialists. The health promotors who were belonging to the rural units within the selected villages guided the researchers during the household community-based survey.

\section{Sample technique and size}

\section{Sampling}

Two-stage random sampling was used; households were randomly selected from the targeted villages in the selected governorates, and then one ever married woman during her childbearing period aged 15-49 years was randomly selected from each household. Selection of the targeted participants was selected after obtaining the map of each village to cover the catchment areas of the targeted 21 villages. Such selection ensured accuracy and reliability of the obtained data.

Sampling was conducted to meet the division of reproductive health's standards (DRH) at the center for disease control and prevention of point estimates within $\pm 3.5 \%$ (two-sided width $=0.07$ ) of the true population prevalence, with $95 \%$ confidence and estimated response rate of $80 \%$. Accordingly, a sample size of 810 produces a two-sided $95 \%$ confidence interval $(\mathrm{Cl})$ with a width equal to 0.07 , when the sample proportion is 0.5 [28], [29].

The exact sample size was $(810+20 \%$ losses) $=972$ which was rounded up to 1000 . The households were selected randomly. 1000 childbearing women (aged 15-49) and 1000 of their husbands completed the survey.

\section{methods}

\section{Quantitative variables and statistical}

All completed questionnaire forms were entered in the computer. Statistical Package of Social Science Software program (SPSS), version 22.0 software (IBM SPSS Statistics for Windows, Version 22.0. Armonk, NY: IBM Corp). Descriptive statistics in the form of mean, Standard deviation, frequency, and percentage were used for data summarization. The analysis was done using, $t$ test between means, chi-square test, and Z-test between proportions. Comparisons between different social media channels versus traditional media channels was done using odds ratios (OR) and 95\% $\mathrm{Cl}$. Multivariate logistic regression (Enter Wald) was 
done for CCs that showed statistical significance in the univariate logistic regression analysis, to adjust and control the effect of confounding variables to prioritize the most exposed and credible CCs between wives and husbands. Significant association is considered if the $95 \% \mathrm{Cl}$ does not include the value 1.0. In this study, a cut-off $p<0.05$ is used for all tests as a measure of statistical significance and considered statistically highly significant if $p<0.01$ [30].

\section{Ethics approval and consent to participate}

The study complied with the International Ethical Guidelines for Biomedical Research Involving Human Subjects [31]. Medical Research Ethical Committee - National Research Centre of Egypt has cleared the study protocol with ethical approval registration number 10,140 . Informed written consent was obtained from all participants involved in the study. Information obtained at the individual level was kept strictly confidential. A worthy note to mention that although the study was looking for the child marriage with the age of both wives and their husbands $<18$ years, yet the actual current age of the surveyed women and their husbands were in the age range (19-40 years) and (21-45 years), respectively. All participants were above the age of 18 at the time of their enrollment for the study. Accordingly, there were no need for their parents/ guardians' consent on their behalf. The information disclosure "Making sure patients understand" was guaranteed according to the recommendations of the Egyptian patients and guardians' perception about clinical informed consent as preferred purposes for IC practices [32].

\section{Results}

The study segmented the surveyed women and their husbands regarding their demographic characteristics. Table 1 shows that more than half of the surveyed women $(63.7 \%)$ were $<25$ years old which lies in the adolescent age versus one third of their husbands $(30.1 \%)$ with a mean age of $23.9 \pm 5.8$ for wives versus $31.2 \pm 8.4$ for husbands with statistically significant difference $(p<0.001)$. As regards the age at the first marriage, it was noticed that almost two thirds of women $(69.5 \%)$ and one-third of husbands (40.7\%) married at an age $<19$ years with statistically significant difference $(p<0.001)$. Moreover, most surveyed women $(96.6 \%)$ were married at an age ranging from 15 to 24 years versus $83.4 \%$ of husbands, which lies in the adolescent age.

Forty percent of surveyed wives were illiterate versus $20.6 \%$ of their husbands followed by $30.7 \%$ and $37.2 \%$ had secondary or equivalent education for wives
Table 1: Demographic characteristics of the surveyed women and their husbands, Upper Egypt

\begin{tabular}{|c|c|c|}
\hline Demographic characteristics $^{*}$ & $\mathrm{n}$ & $\%$ \\
\hline \multicolumn{3}{|l|}{ Current wives age } \\
\hline$<25$ years & 637 & 63.7 \\
\hline $25-<35$ years & 287 & 28.7 \\
\hline$\geq 35$ years & 76 & 7.6 \\
\hline Mean current age of wives \pm SD (range) & \multicolumn{2}{|c|}{$23.89 \pm 4.8(19-40)$} \\
\hline \multicolumn{3}{|l|}{ Current husbands Age } \\
\hline$<25$ years & 301 & 30.1 \\
\hline $25-<35$ years & 111 & 52.3 \\
\hline$\geq 35$ years & 176 & 17.6 \\
\hline Mean current age of husbands \pm SD (range) & \multicolumn{2}{|l|}{$28.2 \pm 6.4(21-45)$} \\
\hline \multicolumn{3}{|l|}{ Wives age at first marriage } \\
\hline$<19$ years & 695 & 69.5 \\
\hline$\geq 19$ years & 305 & 30.5 \\
\hline Mean age at 1 st marriage for wives \pm SD (range) & \multicolumn{2}{|l|}{$19 \pm 3.0(16-22)$} \\
\hline \multicolumn{3}{|l|}{ Husbands age at first marriage } \\
\hline$<19$ years & 407 & 40.7 \\
\hline$\geq 19$ years & 593 & 59.3 \\
\hline Mean age at 1 st marriage for husbands $\pm S D$ (range) & \multicolumn{2}{|c|}{$25.6 \pm 4.9(15-30)$} \\
\hline \multicolumn{3}{|l|}{ Wives' Education } \\
\hline Illiterate & 403 & 40.3 \\
\hline Read \& write/Primary/Prep & 253 & 25.3 \\
\hline Secondary or equivalent (technical-vocational) & 307 & 30.7 \\
\hline University or higher & 37 & 3.7 \\
\hline \multicolumn{3}{|l|}{ Husbands' Education } \\
\hline Illiterate & 206 & 20.6 \\
\hline Read \& write/Primary/Prep & 399 & 39.9 \\
\hline Secondary or equivalent (technical-vocational) & 372 & 37.2 \\
\hline University or higher & 23 & 2.3 \\
\hline \multicolumn{3}{|l|}{ Wives' employment } \\
\hline Employed & 41 & 4.1 \\
\hline Unemployed & 959 & 95.9 \\
\hline \multicolumn{3}{|l|}{ Husbands' employment } \\
\hline Employed & 873 & 87.3 \\
\hline Unemployed & 127 & 12.7 \\
\hline \multicolumn{3}{|l|}{ Type of residence immediately after marriage } \\
\hline Nuclear family & 315 & 31.5 \\
\hline Joint family & 685 & 68.5 \\
\hline
\end{tabular}

and husbands, respectively, with statistically significant difference between their pattern of distribution $(p<0.001)$. The great majority of studied women (about $96 \%$ ) were housewives while about $60 \%$ of their husbands had paid work as craftsmen or builders. About two-thirds of the surveyed groups lived as joint family with the husband's or wife's parents, or one of them or with their relatives. On the other hand, about one-third of wives had their house alone with their husbands.

TV was the most accessible mean of mass media for both husbands and wives (92.7\%) followed by reading then the radio. The least accessibility was to android mobiles (31.7\% of wives and $34.3 \%$ ) of husbands with insignificant difference between them followed by computers and/or laptops (24.0\%). When comparing the frequency of exposure of wives to their husbands, wives were significantly more exposed to both watching TV $(72.5 \%$ vs. $63.3 \%)$ and to reading $(31.3 \%$ vs. $18.4 \%)$ with statistically significant difference between them ( $p$ of $z$ test $<0.05$ ). Whereas exposure to the android mobiles was the same for both wives and husbands, the exposure to computers and/or laptops was limited to a small percentage (18.2\% of husbands and $10.5 \%$ of wives). When comparing the exposure to traditional media versus modern social media, the exposure of wives and husbands to television were nearly 6 and 5 times than that to the android mobiles (OR $=5.6$ and 4.7 , respectively) with high statistical significance. On the contrary, exposure to reading and android mobiles was nearly equal among wives $(\mathrm{OR}=0.9)$ and insignificantly lower among husbands 
$(\mathrm{OR}=0.6)$. Reading sources included newspapers and magazines. Meanwhile, for both wives and husbands, the exposure to radio were equally significantly less than that of the android mobiles (OR = 0.3) (Table 2).

Table 2: Reach (accessibility) and Frequency of the exposure to mass media and social media channels

\begin{tabular}{|c|c|c|}
\hline Channels & $\begin{array}{l}\text { Wives } \\
\mathrm{N}=1000 \\
\text { No }(\%)\end{array}$ & $\begin{array}{l}\text { Husbands } \\
N=1000 \\
\text { No }(\%)\end{array}$ \\
\hline \multicolumn{3}{|l|}{ Accessibility to Media } \\
\hline \multicolumn{3}{|l|}{ Reach to Traditional Mass Media } \\
\hline Availability of T.V & $920(92.7)$ & \\
\hline Reading (Newspapers/Magazines/Booklets/Posters) & $565(56.7)$ & $774(77.4)^{\star \star}$ \\
\hline Radio & $326(32.6)$ & \\
\hline \multicolumn{3}{|l|}{ Reach to Social Media } \\
\hline Mobiles $^{@}$ & $890(89.7)$ & $986(98.6)^{\star \star}$ \\
\hline Availability of Android mobiles & $317(31.7)$ & $343(34.3)$ \\
\hline \multirow{2}{*}{\multicolumn{3}{|c|}{ Frequency of Exposure to Media }} \\
\hline & & \\
\hline \multicolumn{3}{|l|}{ Frequency of exposure to Traditional Mass Media } \\
\hline T.V ${ }^{\circledR}$ & $725(72.5)$ & $633(63.3)^{\star *}$ \\
\hline Reading (Newspapers/Magazines/Booklets/Posters) & $313(31.3)$ & $184(18.4)^{\star *}$ \\
\hline Radio & $140(14.0)$ & $126(12.6)$ \\
\hline \multicolumn{3}{|l|}{ Frequency of exposure to Social Media } \\
\hline Functioning Mobiles & $890(89.7)$ & $986(98.6)^{\star \star}$ \\
\hline Android mobiles & $317(31.7)$ & $266(26.6)$ \\
\hline Computer and/or lap top & $105(10.5)$ & $182(18.2)^{\star \star}$ \\
\hline \multicolumn{3}{|l|}{ Odds of Exposure } \\
\hline OR $(95 \% \mathrm{Cl})$ for exposure to TV vs android mobiles & $5.6(4.6-6.8)^{\star *}$ & $4.7(3.9-5.7)^{\star \star}$ \\
\hline $\begin{array}{l}\text { OR }(95 \% \mathrm{Cl}) \text { for exposure to reading vs android } \\
\text { mobiles }\end{array}$ & $0.9(0.8-1.1)$ & $0.6(0.5-0.7)^{\star \star}$ \\
\hline OR $(95 \% \mathrm{Cl})$ for exposure to radio vs android mobiles & $0.3(0.2-0.4)^{\star \star}$ & $0.3(0.3-0.5)^{\star \star}$ \\
\hline
\end{tabular}

Assessing the managerial feasibility found that $81.5 \%$ of wives and $74.2 \%$ of husbands who watched TV spent $<3 \mathrm{~h} /$ day with significant difference between wives and their husbands. Meanwhile, half of the wives and their husbands $(48.5 \%$ vs. $47.0 \%$, respectively) spent $>5 \mathrm{~h} /$ day on android mobiles for the use of the social media with insignificant difference. For reading, there are insignificant preferences for both wives and their husbands (Table 3 ).

Table 3: Managerial feasibility of the three most exposed mass and social media among target audience, Upper Egypt (time of watching TV or using social media)

\begin{tabular}{|c|c|c|c|}
\hline Favorite channels $^{0}$ & $\begin{array}{l}\text { Wives } \\
\text { No (\%) }\end{array}$ & $\begin{array}{l}\text { Husbands } \\
\text { No (\%) }\end{array}$ & $p$-value of $z$ test \\
\hline Watching TV & $\mathrm{No}=725$ & $\mathrm{No}=633$ & \\
\hline Less than $3 \mathrm{~h} /$ day & $591(81.5)$ & $470(74.2)^{\star}$ & $<0.05^{\star}$ \\
\hline $3-5 \mathrm{~h} /$ day & $86(11.9)$ & $94(14.8)$ & $<0.05^{*}$ \\
\hline$>5 \mathrm{~h} /$ day & $48(6.6)$ & $69(11.0)$ & $<0.001^{* *}$ \\
\hline Exposure to Social Media on Mobiles & $\mathrm{No}=317$ & $\mathrm{No}=266$ & \\
\hline Less than $3 \mathrm{~h} /$ day & $130(41.1)$ & $87(32.7)$ & $<0.001^{* *}$ \\
\hline $3-5$ h/day & $33(10.4)$ & $54(20.3)$ & $<0.001^{\star *}$ \\
\hline$>5 \mathrm{~h} / \mathrm{day}$ & $154(48.5)$ & $125(47.0)$ & $>0.05$ \\
\hline Reading & $\mathrm{No}=313$ & $\mathrm{No}=184$ & \\
\hline Once a month & $82(26.2)$ & $41(22.3)$ & $<0.001^{* *}$ \\
\hline Once a week & $96(30.7)$ & $49(26.6)$ & $<0.05^{*}$ \\
\hline $2-3$ times a week & $32(10.2)$ & $18(9.8)$ & $>0.05$ \\
\hline Almost every day & 58 (18.5) & $38(20.7)$ & $>0.05$ \\
\hline Once per day or more & $11(3.5)$ & $14(7.6)$ & $<0.001^{* *}$ \\
\hline Irregular & $34(10.9)$ & $24(13.0)$ & $>0.05$ \\
\hline
\end{tabular}

Among both husbands and wives who watched TV, satellite channels were much more preferred than local channels with significant statistical difference between them $(p<0.05)$ (Figure 1).

The most favorite programs through which messages could be received by wives and husbands were drama and series (48.4\% and $85.6 \%$, respectively) followed by cooking programs for wives (32.6\%) and specialized programs (talk show) $(65.1 \%)$ for husbands with highly significant difference between the wives and their husbands concerning the preference of the favorite programs $(<0.001)$ (Figure 2).

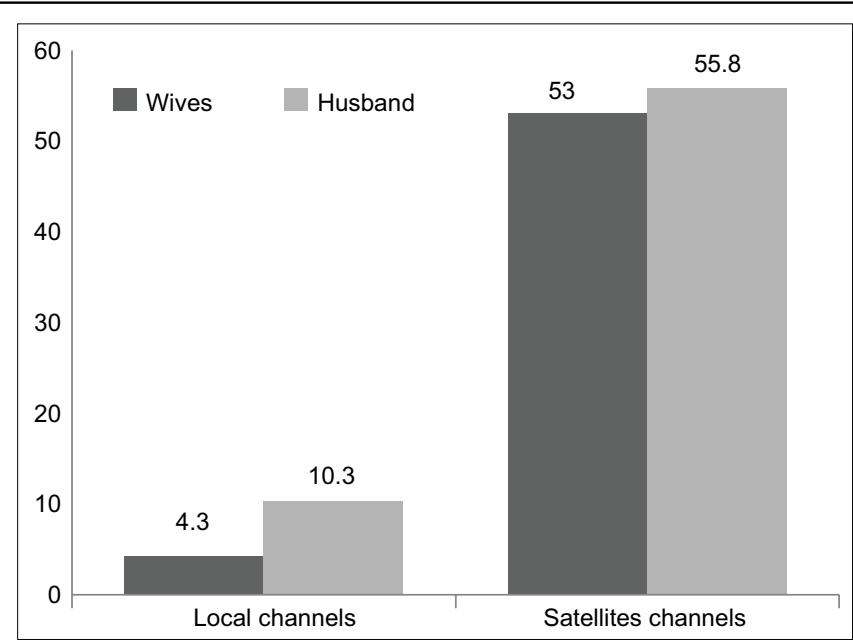

Figure 1: Favorite TV channels (managerial feasibility)". "Percentage calculated out of those who reported that they are watching.

Assessment of the effectiveness for the most credible information sources and the best-suited CCs methods and means to reach the target groups was shown in the Table 4 . The assessment revealed that the most credible sources of information for receiving messages by most husbands and wives were interpersonal communication with health promoters (39.3\% for husbands and $49.1 \%$ for wives, $(p<0.05$ ) followed by doctors (48.7\% of wives), and nurses $(35.5 \%$ of husbands) with significant difference between wives and their husbands ( $p<0.05)$. A high percentage of the target group expressed their desire to receive messages through direct talk with doctors (58\% of husbands and $65.3 \%$ of wives) or with health promoter ( $44.2 \%$ of husbands and $57 \%$ of wives), with significant difference $(p<0.001)$. TV (as a traditional channel) followed by YouTube videos was the second source $38.3 \%$ and $27.8 \%$ for husbands and $42.6 \%$ and $31.7 \%$ for wives, respectively $(p>0.05)$. The third most desirable channel was messaging with friends/relatives/ neighbors through "Whats app" application (27.3\% of husbands and $30.7 \%$ of wives) with insignificant difference. Furthermore, for wives, talk with doctors or health promotors was 2 times significantly higher as the most credible and favorite channels than that with search on you tube $(O R=2.0$ and $O R=2$, respectively)

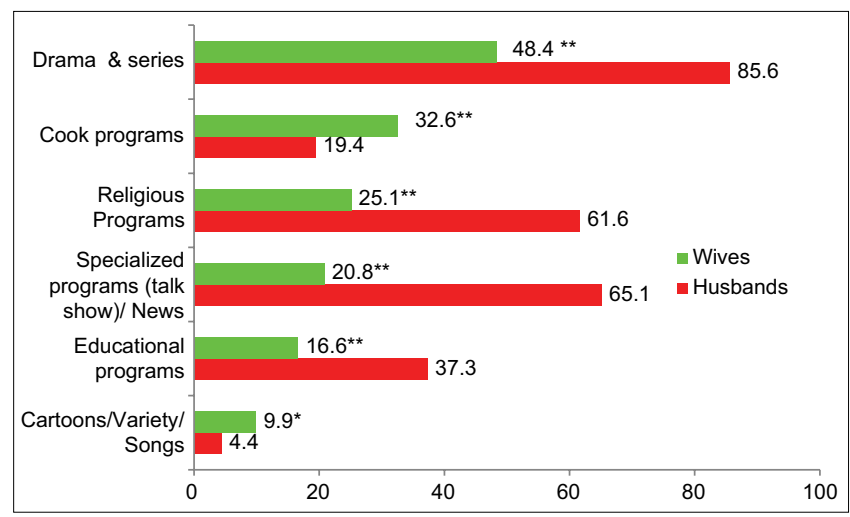

Figure 2: List of Favorite Programs in TV, Upper Egypt. N.B. ${ }^{* *}$ Highly significant statistical difference, *Significant statistical difference 
Table 4: Listing of channels through which messages for reproductive health promotion were received by target audience (most credible information source vs. the most favorite), Upper Egypt

\begin{tabular}{|c|c|c|c|c|}
\hline \multirow[t]{2}{*}{ Channels } & \multicolumn{2}{|l|}{$\begin{array}{l}\text { Wives } \\
N=1000 \\
\text { No }(\%)\end{array}$} & \multicolumn{2}{|l|}{$\begin{array}{l}\text { Husbands } \\
N=1000 \\
\text { No }(\%)\end{array}$} \\
\hline & Most credible & Most favorite & Most credible & Most favorite \\
\hline \multicolumn{5}{|l|}{ Social Media } \\
\hline Search on YouTube & $317(31.7)$ & $317(31.7)$ & $278(27.8)$ & $268(26.8)$ \\
\hline messaging with friends/relatives/neighbors through WhatsApp & $132(13.2)$ & $307(30.7)$ & $113(11.3)$ & $273(27.3)$ \\
\hline Social media through Facebook group and/or twitter & $233(23.3)$ & $192(19.2)$ & $285(28.5)$ & $314(31.4)$ \\
\hline Search through search browser engine (e.g. Google, Microsoft edge...etc.) & $10(1.0)$ & $70(7.0)$ & $35(3.5)$ & $85(8.5)$ \\
\hline \multicolumn{5}{|l|}{ Traditional Mass Media } \\
\hline T.V & $426(42.6)$ & $74(7.4)$ & $383(38.3)$ & $163(16.3)$ \\
\hline Newspapers/Magazines/Booklets/Posters & $104(10.4)$ & $537(53.7)$ & $99(9.9)$ & $545(54.5)$ \\
\hline Radio & $91(9.1)$ & $90(9.0)$ & $66(6.6)$ & $101(10.1)$ \\
\hline OR $(95 \% \mathrm{Cl})$ for TV vs search on You Tube & $1.5(1.3-1.9)^{\star \star}$ & & $1.6(1.3-1.9)^{\star *}$ & \\
\hline OR $(95 \% \mathrm{Cl})$ for TV vs search on social media & $2.4(2.0-2.9)^{\star \star}$ & & $1.5(1.2-1.8)^{\star *}$ & \\
\hline \multicolumn{5}{|l|}{ Interpersonal communication } \\
\hline Religious leaders & $150(15.0)$ & $246(24.6)$ & $181(18.1)$ & $316(31.6)$ \\
\hline Talk with partner & $257(25.7)$ & $279(27.9)$ & $241(24.1)$ & $292(29.2)$ \\
\hline Talk with Doctors & $487(48.7)$ & $653(65.3)$ & $348(34.8)$ & $580(58.0)$ \\
\hline OR $(95 \% \mathrm{Cl})$ for Talk with the doctor vs search on You Tube & $2.0(1.7-2.4)^{\star \star}$ & & $1.3(1.1-1.6)^{\star \star}$ & \\
\hline OR $(95 \% \mathrm{Cl})$ for Talk with the doctor vs Search using browser engine & $3.1(2.5-3.7)^{\star \star}$ & & $1.3(1.1-1.6)$ ** & \\
\hline - Talk with Nurses & $417(41.7)$ & $498(49.8)$ & $355(35.5)$ & $446(44.6)$ \\
\hline OR $(95 \% \mathrm{Cl})$ for Talk with the nurse vs search on You Tube & $1.5(1.2-1.8)^{\star \star}$ & & $1.4(1.1-1.7)^{\star \star}$ & \\
\hline OR $(95 \% \mathrm{Cl})$ for Talk with the nurse vs search using browser engine & $2.3(1.9-2.8)^{\star *}$ & & $1.3(1.1-1.6)^{\star *}$ & \\
\hline - Talk with health promoters & $491(49.1)$ & $570(57.0)$ & $393(39.3)$ & $442(44.2)$ \\
\hline OR $(95 \% \mathrm{Cl})$ for Talk with the health promoter vs search on You Tube & $2.0(1.7-2.4)^{\star \star}$ & & $1.6(1.3-2.0)^{\star *}$ & \\
\hline OR $(95 \% \mathrm{Cl})$ for Talk with the health promoter vs search using browser engine & $3.1(2.6-3.8)^{\star *}$ & & $1.6(1.3-1.9)^{\star *}$ & \\
\hline
\end{tabular}

and 3 times higher than that for social media using browser engine (OR $=3.1$ for each). For husbands, the odds were nearly one and half for all (Table 4). The second most credible and favorite channels for both wives and husbands were TV which carry more than $1 \frac{1}{2}$ times significantly higher incidence than that with search on you tube (OR $=1.5$ and 1.6 , respectively) or social media ( $\mathrm{OR}=2.4$ and $\mathrm{OR}=1.5$ respectively).

RHP messages that were most received by the target group were those about risky pregnancy $(58.6 \%$ of wives and $48.7 \%$ of husbands) and family planning ( $31.6 \%$ of husbands and $51.6 \%$ of wives). Statistically significant difference was observed for all the messages received in favor of wives except the messages related to reproductive tract infection (Table 5).

Table 5: Messages for reproductive health promotion received by husbands and wives, Upper Egypt as reported by participants

\begin{tabular}{|c|c|c|c|}
\hline Channels & $\begin{array}{l}\text { Wives } \\
N=1000 \\
\text { No }(\%)\end{array}$ & $\begin{array}{l}\text { Husbands } \\
\mathrm{N}=1000 \\
\text { No }(\%)\end{array}$ & $p$-value of $z$ test \\
\hline $\begin{array}{l}\text { Pregnancy and labor and their risks including } \\
\text { risk of abortion }\end{array}$ & $586(58.6)$ & $487(48.7)$ & $<0.001^{\star *}$ \\
\hline Messages about family planning and spacing & $516(51.6)$ & $316(31.6)$ & $<0.001^{\star *}$ \\
\hline $\begin{array}{l}\text { Messages about antenatal care, and safe } \\
\text { delivery }\end{array}$ & $456(45.6)$ & $75(7.5)$ & $<0.001^{* *}$ \\
\hline $\begin{array}{l}\text { Reproductive tract infection health education } \\
\text { messages }\end{array}$ & $286(28.6)$ & $275(27.5)$ & $>0.05$ \\
\hline Guidelines to safe delivery & $32(3.2)$ & $52(5.2)$ & $<0.05^{*}$ \\
\hline
\end{tabular}

Table 6 showed the intention of wives and husbands toward postponing the early marriages for their children and postponing pregnancy of their daughters $>19$ years according to their most credible source of information. Most of wives reported that they are going to postpone their daughters' marriage after their 18 years and more than half of them encourage postponing their daughters' first pregnancy compared to less than half of the husbands. More than one-third of husbands were not certain about their intentions for either of them. Significant difference was detected in favor of the traditional media as the most credible source of information only for wives' intention to postpone their children early marriage. There was insignificant influence of the type of the most credible source of information on encouraging the postponing of the pregnancy of their daughters for more than 19 years.

Multivariate logistic regression analysis was done to priorities and identify the likelihood of the exposure and most credible CCs for both wives and husbands (Table 7). While the exposure to reading and to android mobiles were the same for wives and their husbands, exposure to radio was significantly higher for husbands by nearly $50 \%(\operatorname{Exp}(B)=0.46)$. Exposure of wives to T.V was nearly twice that of husbands $(\operatorname{Exp}(B)$ $=1.87$ ). The most credible channels that reported by wives and husbands (Table 4) were investigated. Talk with the health promotors was nearly 3 times higher for wives than that of husbands $(\operatorname{Exp}(B)=3.67)$ as most credible source of information followed by talk with nurses $(\operatorname{Exp}(B)=1.74)$. Meanwhile talk with physicians was nearly the same for both wives and husbands

\section{Discussion}

Important decisions in our lives are not necessarily made by the right, the best or the smartest person but rather by the person who has the power to make that decision especially in young age groups where individuals cannot give consent as in adolescence. Decision makers in any society are a key group that must be targeted and approached due to their direct influence on changing the beliefs and awareness of people living in that society. Many wives in the current study reported that they follow the beliefs 
Table 6: Intention of wives and husbands towards early marriages and postponing pregnancy according to the most credible information source (social vs. traditional media)

\begin{tabular}{|c|c|c|c|c|c|c|}
\hline \multirow[t]{3}{*}{ Factors } & \multicolumn{3}{|l|}{ Wives $^{\S}$} & \multicolumn{3}{|l|}{ Husbands $^{\S}$} \\
\hline & Definitely do & May be & Definitely do not & Definitely do & May be & Definitely do not \\
\hline & $\mathrm{n}(\%)$ & $\mathrm{n}(\%)$ & $\mathrm{n}(\%)$ & $\mathrm{n}(\%)$ & $\mathrm{n}(\%)$ & $\mathrm{n}(\%)$ \\
\hline \multicolumn{7}{|c|}{ Postponing their children's marriage to $>18$ years } \\
\hline Social media & $261(82.3)$ & $56(17.7)$ & - & $132(47.4)$ & $124(44.4)$ & $23(8.2)$ \\
\hline Traditional media & $450(91.6)$ & $41(8.4)$ & & $196(49.9)$ & $160(40.7)$ & $37(9.4)$ \\
\hline \multicolumn{7}{|c|}{ Encourage postponing $1^{\text {st }}$ pregnancy of their daughters $>19$ years } \\
\hline Social media & $194(61.2)$ & $52(16.4)$ & $71(22.4)$ & $94(33.7)$ & $107(38.4)$ & $78(28.0)$ \\
\hline Traditional media & $311(63.3)$ & $98(20.0)$ & $82(16.7)$ & $152(38.7)$ & $160(40.7)$ & $81(20.6)$ \\
\hline$p$-value for $X^{2}$ & $p>0.05$ & & & $p>0.05$ & & \\
\hline
\end{tabular}

of their husbands for all life decisions and even for HP related issues. Meanwhile, in rural communities, refusal of husbands was reported by many wives to be the most common barrier to their referral to health services [17], [18], [33]. Based on all the above findings and facts, women and their husbands were considered as the priority target groups for the current study.

Table 7: Multivariate Logistic regression model for prioritization of the exposure and credible communication Channels between wives and husbands

\begin{tabular}{llll}
\hline Parameters\# & COR (Cl 95\%) & AOR & Cl \\
& & & $95 \%$ C.I. \\
\hline Exposure to radio (wives) & $0.79(0.62-0.88)^{*}$ & 0.46 & $0.35-0.56^{*}$ \\
Exposure to reading (wives) & $2.0(1.6-2.48)^{*}$ & 1.00 & $0.99-1.01$ \\
Exposure to android mobiles (wives) & $1.28(1.05-1.55)^{*}$ & 0.90 & $0.75-1.08$ \\
Exposure to TV (wives) & $1.53(1.27-1.84)^{\star}$ & 1.87 & $1.35-2.59^{*}$ \\
Most credible Talk with nurses (wives) & $1.78(1.40-2.13)^{*}$ & 1.74 & $1.45-2.10^{*}$ \\
Most credible Talk with physicians (wives) & $1.30(1.08-1.56)^{*}$ & 1.00 & $0.98-1.02$ \\
Most credible Talk with health promoters (wives) & $1.50(1.24-1.78)^{*}$ & 3.67 & $2.80-4.80^{*}$ \\
Constant & & 0.043 & \\
\hline "Wives were the base of the study, ${ }^{*} p<0.05$. & & &
\end{tabular}

In the field of health, substantial evidence shows that people are willing to change their health behavior irrespective to the health condition. It is therefore important to identify channels of communications through which HP messages that contribute to promotion of reproductive health should be disseminated to the specific target audience. Nowadays, health care messages, including reproductive health, are increasingly being delivered through digital channels such as the internet, mobile phone messaging, social media, apps, voice/video messaging, and telemedicine. These ways have proven to be effective in developed countries, yet in developing countries many barriers such as infrastructure, lack of equipment, and technology gap hinder their successful implementation [34], [35], [36], [37].

Although social media is an acceptable and usable among multiple audiences and appeared to be promising in promoting health equity among disadvantaged populations especially low-income communities [38], [39], yet, the effectiveness of social media in improving public health outcomes including RHP and reduction of child marriage is questionable in rural communities compared to urban settings. In rural areas, there is negative association with computer access and use of modern technology that can be attributed to variables as poor internet connections, poverty, and lower level of education [40]. Traditional media is therefore fundamental in rural communities as it disseminate the information which shapes the public, so it plays a major role in changing the risky attitudes and behaviors of the targeted audience [20].

In the current study, the internet was not a first choice for the participants as a source of reproductive health information as only one-third of them had access to android phones. Interpersonal communication appeared to be the most credible source of information and the most favorite channel through which RHP messages could be received by target audience. Talking with health promoter $(39.3 \%$ for husbands and $49.1 \%$ for wives) and talking with doctors $(48.7 \%$ of wives) came as the most important means for both wives and husbands followed by TV $(42.6 \%$ of wives and $38.3 \%$ of husbands). This result is like that of many previous old and recent studies as well, who assessed the effectiveness of broadcasted media versus interpersonal channels in delivering health messages to the public [41], [42], [43], [44], [45], [46]. They reported that in low and moderate socioeconomic societies, interpersonal communication serves as primary health information sources for health- oriented individuals with strong health beliefs and commitment to healthy activities, while passive consumption channels such as television and radio serve as primary health information sources for individuals in low socioeconomic societies and who are not health-oriented. Unfortunately, neither one of these studies assessed the reach, frequency, managerial feasibility nor the effectiveness of the recent social media channels versus the traditional ones as tool for HP.

In the present study, on investigating the channels of communication through which RHP messages could be disseminated, the percentages of wives who had accessibility to TV, radio and reading media were $72.5 \%, 14 \%$ and $31.3 \%$, respectively, while for the husbands the percentages were $63.3 \%$, $12.6 \%$, and $18.4 \%$, respectively. This indicates more accessibility of wives and their husbands to TV as a main source for health information within Egyptian families. TV serials have been proven as a very successful means of 'edutainment" as well.' They usually convey a particular theme which can possibly influence viewers' behavior [47], [48], [49].

Assessing the managerial feasibility will help in the identity of the possibilities to be targeted for any future interventions depending on the exposure over 
time through detecting the top three types of media and platforms to which the target audience were most exposed. The current study found television stations as key partners in disseminating messages for promoting public health. The current study revealed that the more than three quarters of wives $(81.5 \%)$ and husbands $(74.2 \%)$ spent $<3 \mathrm{~h} /$ day watching televisions watching drama and series $(48.4 \%$ and $85.6 \%$, respectively). This finding was in accordance with an old study dated 1999 that was done by the National Research Council (US) and Institute of Medicine (US) Board on children, youth, and families [49], indicating that the situation still the same in rural communities despite of the nowadays widespread of the social media, whereas only half of those reported to have android mobiles spent up to $5 \mathrm{~h} /$ day on android mobiles. This finding indicate that future programs should rely on mass media rather than social media for the large and broad campaigns to target rural communities. An example in Egypt that is proved to be successful one with the use of mass media is a soap opera called "The Family House" which reached out to millions of Egyptians with health messages on issues such as AIDS, drugs, child spacing, home accidents, and hygiene [50], [51]. Another example is a soap opera on the South African television that was run by public health activists over $70 \%$ of the population addressing, from HIV and AIDS to rape [52].

For wives, talk with doctors or health promotors was 2 times significantly higher as the most credible information sources and the best-suited CCs methods than that with search on you tube $(O R=2.0$ and $\mathrm{OR}=2$, respectively) and 3 times higher than that for social media using browser engine ( $O R=3.1$ for each). For husbands, the odds were nearly one and half for all. This was in accordance with many Egyptian studies which have achieved their goals for improving behaviors for many health-related diseases and issues with the aid of the health promotors, community leaders or health care workers; for example, reduction of maternal mortality [17], [18], [53], improving environmental health [54], [55], alleviating children anemia [56], counteracting barriers against diabetes [57], and accelerating HCV elimination [59], [60], [61]. These studies are mainly community-based studies in rural communities respecting the culture and believe within their communities. Other Egyptian studies that relay on the nurses and physician for facility-based studies addressing several health issues from improvement of cognitive function [62], children's nutritional habits [9], [63], [64], improving response of HBV among children [65], [66], and improving compliance with hemodialysis patients [67], [68]. All these health communication programs were proved to be helping aid for people make these changes especially for rural communities of Egypt using the most credible and favorite channels. In accordance with these facts, the intention of wives toward postponing their children early marriage was significantly higher among those who considered traditional channel as their most credible source than social media. For husbands and for intention of encouraging the postponing of their daughters' first pregnancy to more than 19 years was similar between the two types of media indicating that once the target group is reached, he can be persuaded by certain idea. This indicates that the problem is not with the channel use or the most credible one, but it is related to the accessible type that is influenced by the locality.

\section{Conclusion}

Application of cost-effective strategies for tackling rural health problems required CCs assessment to identify the on-ground situation to meet the unmet need for not only the problem of child and adolescent marriage but also facing any health problem. Despite the availability of recent social media worldwide, what worked worldwide was not the situation for rural communities, with high illiteracy, limited access to the internet, and limited availability of smartphones. For rural communities and with the widespread of many health problems, the most credible information sources and the best-suited CCs methods for delivering reproductive health messages are interpersonal communication through health promoters followed by doctors and nurses. Television, being the most favored and most accessible mass media channel, plays important roles in terms of conveying information, stimulating thought, informing, and developing ideal behavior.

\section{Recommendations}

It seems vital during the implementation of any preset strategies for reproductive health to use not only the media broadcasts to promote reproductive health but also to rely on the channels that are most credible and suitable for the targeted communication. For rural communities in special, the used media must be embedded in the settings in which people live through the health promoters in the community setting and by professionals in clinics rather than being delivered through social media. These types of efforts would improve women's and men's abilities to meet their childbearing goals and empower country directions toward fulfillment of the global SDGs to ensure equality by 2030 .

\section{Strengths of the study}

The current study serves as an exemplary model for facilitating the implementation of the national 
strategies for RHP mainly in rural communities and support meeting the unmet need. The study did not only assess the availability and accessibility of different CCs but also assess their managerial feasibility and credibility as a crucial step for limiting child and adolescents' marriage.

With the still high adolescents' marriage in rural communities of Egypt, this study reports on the problem situation from the holistic point of view and did not dig deeper into linking wives and husbands' characteristics to the use of channels type as it is well known that the use of social media is highly linked with education level and young age.

\section{Limitation of the study}

The study was limited to study only the beneficiaries, without evaluating the impact of CCs use on the reduction of child and adolescent marriage.

\section{Availability of data and materials}

The datasets used and/or analyzed concerning the current study are not publicly available due to the privacy of the studied women and their husbands as any topic related to reproductive health in the rural communities is considered taboo. Meanwhile, all data of the current study are available from the corresponding author on reasonable request.

\section{Authors' Contributions}

AMM conceived and designed the study. RMS, MME, HAA, MHA, HMH1, MAA, HMH2, AM, GAA conducted the field work and data collection. AMM, NAI, $\mathrm{HE}, \mathrm{AMA}$, WAF oversaw the implementation. $\mathrm{HMH} 1$, MAA, HMH2, MME provided clinical examination for all child and adolescents during the clinical conveys during conduction of the field work. RMS, AM, DME, SIS \& IIS did the statistical analyses. RMS, DME, MME shared in the interpretation of the results. RMS drafted the manuscript. AMM \& LEE reviewed the manuscript. RMS \& MME submitted the manuscript. All authors reviewed the manuscript and approved the final version.

\section{Acknowledgment}

The authors express their appreciation to the funding agency, all women, and their husbands for their willing in participation and cooperation.

\section{References}

1. Crone EA, Konijn EA. Media use and brain development during adolescence. Nat Commun. 2018;9(1):588. http://doi. org/10.1038/s41467-018-03126-x

PMid:29467362

2. Sawyer SM, Azzopardi PS, Wickremarathne D, Patton GC. The age of adolescence. Lancet Child Adolesc Health. 2018;2(3):2238. http://doi.org/10.1016/S2352-4642(18)30022-1 PMid:30169257

3. Joint Press Release by UNFPA, UNICEF, WHO, UN Women, the United Nations Foundation, World Vision, Girls Not Brides, Every Woman Every Child, World YWCA and the Partnership for Maternal, Newborn and Child Health. NEW YORK, 7 March 2013. Available from: https://www.un.org/youthenvoy/2013/09/ child-marriages-39000-every-day-more-than-140-milliongirls-will-marry-between-2011-and-2020 [Last accessed on 2020 Nov 28].

4. Abdel-Tawab N, Oraby D, El-Gibaly O, Darwish M, Aziz M, Elgazzar A, et al. Married Adolescent Girls in Rural Assiut and Souhag: Limited Choices and Unfulfilled Reproductive Health Needs. Final Report. Cairo: Population Council; 2017. Available from: https://www.popcouncil.org/uploads/pdfs/2017pgy marriedadolgirlsassiutsouhag.pdf [Last accessed on 2020 Dec 06].

5. CAPMAS, 2017. Egypt Census of Population, Housing and Establishments, Egypt. Available from: https://www.capmas. gov.eg/Pages/ShowPDF.aspx?page_id=/Admin/Pages $\% 20$ Files/201710914947book.pdf [Last accessed ion 2021 Jan 02].

6. UNICEF. Policy for Action: Issue 1. A product of NCCM Child Rights Observatory. Ending Child Marriage. 1-4. 2019. Available from: https://www.unicef.org/egypt/sites/unicef.org egypt/files/2018-06/Child\%20Marriage $\% 20$ Policy\%20Brief\%20 EN\%20FINAL.PDF [Last accessed 2021 Jan 05].

7. Spindler E, Perlman D, Chaibou S, Silverman J, Carter N Boyce $\mathrm{S}$, et al. Child Marriage, Fertility, and Family Planning in Niger: Results from a Study Inspired by the International Men and Gender Equality Survey (IMAGES). Washington, DC: Promundo, US; 2019.

8. Yount KM, Crandall A, Cheong YF. Women's age at first marriage and long-term economic empowerment in Egypt. World Dev. 2018;102:124-34. http://doi.org/10.1016/j. worlddev.2017.09.013

PMid:29422706

9. Metwally AM, El-Sonbaty MM, El Etreby LA, Salah EI-Din EM, Abdel Hamid N, Hussien HA, et al. Impact of national Egyptian school feeding program on growth, development, and school achievement of school children. World J Pediatr. 2020;16(4):393400. http://doi.org/10.1007/s12519-020-00342-8 PMid:32056148

10. Salah El-Din EM, Elabd MA, Nassar MS, Metwally AM, Abdellatif GA, Rabah TM, et al. The interaction of social, physical and nutritive factors in triggering early developmental language delay in a sample of Egyptian children. Open Access Maced J Med Sci. 2019;7(17):2767-74. http://doi.org/10.3889/ oamjms.2019.642

PMid:31844434

11. El Din EMS, Rabah TM, Metwally AM, Nassar MS, Elabd MA Shaalan A, et al. Potential risk factors of developmental cognitive delay in the first two years of life. Open Access Maced J Med Sci. 2019;7(12):2024-30. http://doi.org/10.3889/oamjms.2019.566 PMid:31406549

12. Kandeel WA, Rabah TM, Zeid DA, El-Din EM, Metwally AM, Shaalan A, et al. Determinants of exclusive breastfeeding in a sample of Egyptian infants. Open Access Maced J Med Sci. 
2018;6(10):1818-23. http://doi.org/10.3889/oamjms.2018.359 PMid:30455755

13. Egypt Demographic Household Survey (DHS). Ministry of Health and Population Cairo, Egypt El-Zanaty and Associates Cairo, Egypt. The DHS Program ICF International Rockville, Maryland, USA, Egypt Demographic Household Survey; 2014. Available from: https://dhsprogram.com/pubs/pdf/fr302/fr302. pdf [Last accessed on 2020 Dec 25].

14. Pathfinder International. Launching a New National Strategy for Preventing Child Marriage in Egypt; 2015. Available from: https://www.pathfinder.org/articles/launching-new-nationalstrategy-preventing-child-marriage-egypt [Last accessed on 2020 Dec 05].

15. Egypt Country Brief Child Marriage in the Middle East and North Africa, United Nations Children's Fund (UNICEF) Middle East and North Africa Regional Office in collaboration with the International Center for Research on Women (IRCW); 2017. Available from: https://www.unicef.org/mena/media/1796/ file/MENA-CMReport-EgyptBrief.pdf.pdf [Last accessed 2020 Dec 29].

16. UNFPA, Egypt. United Nation Population Fund: Because Everyone Counts, Global Health Council. Field Note: Addressing the Regional Maternal Mortality in Egypt; 2012: Available from: http://egypt.unfpa.org/english/Staticpage/2/8c040c3a9607-448a-a8c7 b62540496038/Reproductive_Health.aspx; http://www.globalhealth.org/reports/report.php3?id=196 [Last accessed on 2021 Jan 12].

17. Metwally AM, Abdel-Latif GA, Mohsen A, El Etreby L, Elmosalami DM, Saleh RM, et al. Strengths of community and health facilities based interventions in improving women and adolescents' care seeking behaviors as approaches for reducing maternal mortality and improving birth outcome among low income communities of Egypt. BMC Health Serv Res.2020;20(1):592. http://doi.org/10.1186/ s12913-020-05412-1

PMid:32600377

18. Metwally AM, Saleh RM, El-Etreby LA, Salama SI, Aboulghate A, Amer HA, et al. Enhancing the value of women's reproductive rights through community based interventions in Upper Egypt governorates: A randomized interventional study. Int J Equity Health. 2019;18(1):146.

19. Zamawe C, Banda M, Dube A. The impact of a community driven mass media campaign on the utilization of maternal health care services in rural Malawi. BMC Pregnancy Childbirth. 2016;16:21.

20. Nancy NO. Should we keep this quiet? Print media and child marriage in Nigeria. Glob Med J. 2018;16:31.

21. Mehra D, Sarkar A, Sreenath P, Behera J, Mehra S. Effectiveness of a community based intervention to delay early marriage, early pregnancy and improve school retention among adolescents in India. BMC Public Health. 2018;18:732. https://doi.org/10.1186/ s12889-018-5586-3

22. World health Organization. Trends in Maternal Mortality: 1990 to 2013. Estimates by WHO, UNICEF, UNFPA, the World Bank and the United Nations Population Division. Geneva: World health Organization. 2014. Available from: https://apps.who. int/iris/bitstream/handle/10665/112682/9789241507226_eng. pdf; jsessionid=600D59FBF919EF49 11F470E715C3A79B? sequence $=2$ [Last accessed on 2020 Feb 03].

23. Ministry of Economic Development. Millennium Development Goals Report: 2008-Egypt, Achieving the MDGs; Midpoint Assessment; 2010. Available from: http://ebookbrowsee.net/ egypt-mdg-mid-term-assessment-report-2008-pdf-d543877248 [Last accessed on 2020 Oct 25].

24. UNICEF. Writing a Communication Strategy for Development Programs. A Guideline for Program Managers and Communication Officers, Bangladesh; 2008. Available from:
http://etoolkits.dghs.gov.bd/sites/default/files/UNICEF\%20 Writing $\% 20$ a $\% 20$ Communication $\% 20$ Strategy $\% 20$ for\%20Development $\% 20$ Programs.pdf [Last accessed on 2020 Dec 05].

25. UNICEF. Towards better Programming. A Handbook on Behavior Development Communication in Water and Environmental Sanitation Programs. New York: Unpublished Document, UNICEF WES Technical Guidelines Series No. 4, Program Division Guideline Series; 1999a.

26. UNICEF. Meeting Report. Inter-Agency Task Force Consultation on Behavior and Communication from a Rights Perspective. New York: Unpublished Document; 1999b.

27. World Bank. Strategic Communication for Development Projects. The International Bank for Reconstruction and Development. This Toolkit was First Published in 1996 by the World Bank's Human Development Network under the Title Communication for Behavior Change for Task Managers; 2003. Available from: https://openknowledge.worldbank .org/ bitstream/handle/10986/20227/902840WP0Box380C00 toolkitwebjan2004. pdf?sequence=1\&isAllowed=y [Last accessed on 2020 Dec 19].

28. Fleiss JL, Levin B, Paik MC. Statistical Methods for Rates and Proportions. $3^{\text {rd }}$ ed. New York: John Wiley and Sons: 2003. Available from: https://onlinelibrary.wiley.com/doi/ pdf/10.1002/0471445428 [Last accessed on 2020 Nov 01].

29. Newcombe RG. Two-sided confidence intervals for the single proportion: Comparison of seven methods. Stat Med. 1998; 17:857-72.

30. Sheskin DJ. Handbook of Parametric and Nonparametric Statistical Procedures. $3^{\text {rd }}$ ed. Boca Raton: Chapman and Hall/CRC; 2004. Available from: http://fmipa.umri.ac.id/ wp-content/uploads/2016/03/David_J._Sheskin_David_ Sheskin_Handbook_of_ParaBookFi.org_.pdf [Last accessed on 2020 Oct 22].

31. CIOMS/WHO. International Ethical Guidelines for Biomedical Research Involving Human Subjects. Geneva: CIOMS; 1993.

32. Metwally AM, Amer HA, Salama HI, Abd El Hady SI, Alam RR, Aboulghate $A$, et al. Egyptian patients/guardians experiences and perception about clinical informed consent and its purpose: Cross sectional study. PLoS One. 2021;16(6):e0252996. https:// doi.org/10.1371/journal.pone.0252996

33. Metwally AM, Abdel Latif GA, El Etreby L, Tawfik A, Elsayed D, Abdel Mohsen AM. Influence of sociodemographic factors and environmental conditions on husbands' behavior toward maternal healthcare. J Arab Soc Med. 2015;10(1):18-26. https:// doi.org/10.4103/1687-4293.159370

34. Speizer IS, Whittle L, Carter M. Gender relations and reproductive decision making in Honduras international family planning perspectives. Int Fam Plan Perspect. 2005;31(3):131-9. https:// doi.org/10.1363/3113105

PMid: 16263530

35. Kyilleh JM, Tabong PT, Konlaan BB. Adolescents' reproductive health knowledge, choices and factors affecting reproductive health choices: A qualitative study in the West Gonja District in Northern region, Ghana. BMC Int Health Human Rights. 2018;18(1):6. https://doi.org/10.1186/s12914-018-0147-5 PMid:29361947

36. Karki YB. Effects of Communication Campaigns on the Health Behavior of Women of Reproductive Age in Nepal. Further Analysis of the 2006 Nepal Demographic and Health Survey; 2008. Available from: https://dhsprogram.com/pubs/pdf/FA51/ FA51.pdf [Last accessed on 2020 Dec 10].

37. Stellefson M, Paige SR, Chaney BH, Chaney JD. Evolving role of social media in health promotion: Updated responsibilities for health education specialists. Int J Environ Res Public Health. 2020;17(4):1153. https://doi.org/10.3390/ijerph17041153 PMid:32059561 
38. Vedal I, Ramaprasad J, Lapointe L. Social media strategies for health promotion by nonprofit organizations: multiple case study design. J Med Internet Res. 2020;22(4):e15586. https:// doi.org/10.2196/15586

PMid:32250282

39. Stermensky G, Ogbeide S. Rural provider attitudes toward the use of social media for patient engagement and retention: A brief report. Int J Complement Altern Med 2017;6(6):207. https://doi. org/10.15406/ijcam.2017.06.00207

40. Elwyn G, Frosch D, Thomson R, Joseph-Williams N, Lloyd A, Kinnersley $P$, et al. Shared decision making: A model for clinical practice. J Gen Intern Med. 2012;27(10):1361-7. https://doi. org/10.1007/s11606-012-2077-6 PMid:22618581

41. Kruse C, Betancourt J, Ortiz S, Luna S, Bamrah I, Segovia N Barriers to the use of mobile health in improving health outcomes in developing countries: Systematic review. J Med Internet Res. 2019;21(10):e13263. https://doi.org/10.2196/13263 PMid:31593543

42. Nwagwu WE. The Internet as a source of reproductive health information among adolescent girls in an urban city in Nigeria. BMC Public Health. 2007;7:354. https://doi. org/10.1186/1471-2458-7-354

43. Giorgio MM, Kantor LM, Levine DS, Arons W. Using chat and text technologies to answer sexual and reproductive health questions: Planned parenthood pilot study. J Med Internet Res. 2013;15(9):e203. https://doi.org/10.2196/jmir.2619 PMid:24055754

44. Bacchus LJ, Reiss K, Church K, Colombini M, Pearson E, Naved $\mathrm{R}$, et al. Using digital technology for sexual and reproductive health: Are programs adequately considering risk? Glob Health. 2019;7(4):507-14. https://doi.org/10.9745/ GHSP-D-19-00239

45. Dart J, GalloisC, Yellowlees P. Community health information sources, a survey in three disparate communities. Aust Health Rev. 2008;32(1):186-96. https://doi.org/10.1071/ah080186 PMid: 18241163

46. Dutta-Bergman MJ. Primary sources of health information: Comparisons in the domain of health attitudes, health cognitions, and health behaviors. Health Commun. 2004;16(3):273-88. https://doi.org/10.1207/S15327027HC1603_1 PMid:15265751

47. Wakefield MA, Loken B, Hornik RC. Use of mass media campaigns to change health behavior. Lancet. 2010;376(9748):1261-71. https://doi.org/10.1016/S0140-6736(10)60809-4 PMid:20933263

48. Goiana-da-Silva F, Cruz-e-Silva D, Carriço M, Teixeira N, Darzi A, Araújo F. Changing the channel: television health campaigns in Portugal. Lancet Public Health. 2019;4(4):e179. https://doi.org/10.1016/S2468-2667(19)30039-8 PMid:30954141

49. National Research Council (US) and Institute of Medicine (US) Board on Children, Youth, and Families. In: Fischhoff B, Crowell NA, Kipke M, editors. Adolescent Decision Making: Implications for Prevention Programs: Summary of a Workshop, Media Influences. Washington, DC: National Academies Press, US; 1999.

50. Laveaga GS. Let's become fewer: Soap operas, contraception, and nationalizing the Mexican family in an overpopulated world. Sex Res Soc Policy. 2007;4(3):19-33.

51. Elkamel FM. Soap operas may be good for health: Impact evaluation of the Egyptian soap opera, family house. Eastern Meditter Health J. 1998;4(1):178-80.

52. Cassidy J. The soap opera that saves lives. BMJ. 2008;336(7653):1102-3. https://doi.org/10.1136/
bmj.39570.422778.3A

53. Metwally AM, Abdel-Latif GA, Saleh RM, Elmosalami DM, Ibrahim NA, Imam HM. Empowerment of medical and paramedical health providers role for achieving the millennium development goal of reducing maternal mortality in Egypt. Eur $J$ Sci Res. 2014;117(1):7-22.

54. Metwally AM, Abdel-Latif GA, Salama SI, Tawfik A, Elmosalami DM, Mohsen AM. Care seeking behaviors of rural women in Egypt: community-based study. J Appl Sci Res. 2013;9(6):3767-80.

55. Metwally AM, Saad A, Ibrahim NA, Emam HM, El-Etreby LA. Monitoring progress of the role of integration of environmental health education with water and sanitation services in changing community behaviours. Int J Environ Health Res. 2007;17(1):6174. https://doi.org/10.1080/09603120600937856 PMid:17365081

56. Metwally AM, Ibrahim NA, Saad A, Abu el-Ela MH. Improving the roles of rural women in health and environmental issues. Int J Environ Health Res. 2006;16(2):133-44. https://doi. org/10.1080/09603120500539208

PMid: 16546806

57. Metwally AM, Hanna C, Galal YS, Saleh RM, Ibrahim NA, Labib NA. Impact of nutritional health education on knowledge and practices of mothers of anemic children in El Othmanyia Village-Egypt. OpenAccess Maced J Med Sci. 2020;8(E):458-65.

58. Metwally AM, Soliman M, Abdelmohsen AM, Kandeel WA, Saber M, Elmosalami DM, et al. Effect of counteracting lifestyle barriers through health education in Egyptian Type 2 diabetic patients. Open Access Maced J Med Sci. 2019;7(17):2886-94. https://doi.org/10.3889/oamjms.2019.624

PMid:31844454

59. Metwally AM, Elmosalami DM, Elhariri H, El Etreby LA, Aboulghate A, El-Sonbaty MM, et al. Accelerating Hepatitis $C$ virus elimination in Egypt by 2030: A national survey of communication for behavioral development as a modelling study. PLoS One. 2021;16(2):e0242257. https://doi.org/10.1371/journal.pone.0242257 PMid:33621232

60. Shiha G, Metwally AM, Soliman R, Elbasiony M, Mikhail NN, Easterbrook P. An educate, test, and treat programme to reduce hepatitis $\mathrm{C}$ in Egypt: Results from a communitybased demonstration project. Lancet Gastroenterol Hepatol. 2018;3(11):778-789. https://doi.org/10.1016/ S2468-1253(18)30139-0 PMid:30030068

61. Metwally A, Mohsen A, Saleh R, et al. Prioritizing high-risk practices and exploring new emerging ones associated with hepatitis $C$ virus infection in Egypt. Iran J Public Health. 2014;43(10):1385-94. PMid:26060701

62. Salah EM, Khalifa AG, Metwally AM, Hamid NA, Hussien HA Moneer ZM. The impact of school snacks on cognitive function of primary school children in Egypt. J Appl Sci Res. 2012;8(12):5639-50.

63. Metwally AM, El-Sonbaty M, El Etreby LA, El-Din EMS, Hamid NA, Hussien HA, et al. Stunting and its determinants among governmental primary school children in Egypt: A schoolbased cross-sectional study. Open Access Maced J Med Sci. 2020;8(B):650-7.

64. Metwally AM, Shaaban FA, Mahmoud WS, Salah EM, El-Sonbaty MM, Hussien HA, et al. Vulnerability and weaknesses of eating habits of overweight school children as an entry risk for COVID-19. Open Access Maced J Med Sci. 2020;8(T1):158-66.

65. Salama II, Sami SM, Said ZN, Salama SI, Rabah TM, AbdelLatif GA, et al. Early and long term anamnestic response to HBV booster dose among fully vaccinated Egyptian children during infancy. Vaccine. 2018;36(15):2005-11. https://doi. 
org/10.1016/j.vaccine.2018.02.103

PMid:29530634

66. Salama II, Sami SM, Nabil Z, Said A, El-Sayed MH, El Etreby LA, et al. Effectiveness of hepatitis $B$ virus vaccination program in Egypt: Multicenter national project. World J Hepatol. 2015;7(22):2418-26. https://doi.org/10.4254/wjh.v7.i22.2418 PMid:26464758

67. Ahmed AM, Allam MF, Metwally AM, Ibrahiem NA, Radwan M,
El Gaafary MM, et al. Compliance with haemodialysis practice guidelines in Egypt. East Mediterr Health J. 2013;19(1):4-9. PMid:23520899

68. Ahmed AM, Allam MF, Habil ES, Metwally AM, Ibrahiem NA, Radwan $M$, et al. Development of practice guidelines for hemodialysis in Egypt. Indian J Nephrol. 2010;20(4):193-202. https://doi.org/10.4103/0971-4065.73450

PMid:21206681 